\title{
2. Origin and Precedence: The construction and distribution of status in the highlands of Bali
}

\section{Thomas A. Reuter}

What are the prospects for a universal theory of status? There is one major obstacle to all generalization attempts in the social sciences: the classes of phenomena they propose to exist and whose existence they seek to explain often show a very limited degree of cross-cultural validity. General theories of 'status' are no exception. The etymology of the word suggests something at a standstill, an image that is difficult to reconcile with the immense variability of status systems across different societies and in the same societies during different historical periods. Obviously, it is the most universal theories of status that also experience the greatest difficulty in accounting for the apparent lack of a universal status distribution pattern or a universal logical principle of status reckoning. However, it does not further the cause of social science simply to avoid the dilemma of generalization. Treating each individual status system as an utterly unique phenomenon is tacitly implying that it cannot be profitably compared to those of other societies. An explicit argument conceived in this spirit, however, would encounter the opposite problem: the status systems of widely separated societies in fact often show remarkable similarity.

This paper adopts an intermediate position. It is proposed that generalizations about status systems (and other social phenomena) across different societies are possible and profitable so long as we are able to offer a reasonable, explicit and testable explanation for the similarities that unite and the differences that distinguish them. A possible explanation for differences and similarities alike is to say that status or 'symbolic capital' is socially constructed by competing individual agents, but not randomly or at their complete liberty. Status is necessarily also constructed in a regulated or co-operative fashion, in accordance with culturally shared principles of classification, communication and social interaction. People who regularly interact thus tend to disagree and agree about one another's status at the same time. In order to explain similarities in cultural principles of status reckoning and distribution across different societies we need not assume the existence of a hypothetical universal structure in the individual mind either. Status systems and the cultures to which they belong are historical and 'fuzzy' systems of communicative and strategic action rather than permanent and easily separable metaphysical entities. Not many societies are clearly bounded or isolated from their neighbours today, and few ever were. In addition, different 
societies with a common historical origin and cultural heritage - though they no longer form a single or tightly cohesive social universe today - may still have many principles of status reckoning and distribution in common.

Indonesian societies, and indeed societies in the Austronesian-speaking world, appear to be related in this way (Fox 1993; Bellwood, Fox and Tryon 1995; Fox and Sather 1996). On the basis of rich historical, linguistic and ethnographic evidence it is thus reasonable to propose that a single theory may suffice to explain many common features and variations in their different status systems. This paper explores how status is constructed and distributed in one of these societies; namely, among the central highland people of Bali.

My results from more than a decade of ethnographic research indicate that it may be profitable to reconsider Balinese society, and its symbolic economy, from the wider perspective of a comparative ethnology of Indonesian and Austronesian societies. ${ }^{1}$ Previous accounts of Hindu Balinese society have tended to stress its uniqueness in a predominantly Islamic Indonesia. These studies focused on the courtly culture of coastal Balinese polities whose rulers trace their origin to the Hindu Javanese kingdom of Majapahit. The more obviously 'Austronesian' heritage of the indigenous 'Mountain Balinese' or Bali Aga people had not been examined in sufficient depth. For the study of a Balinese status system this has meant that the importance of Indic elements (such as the concept of varna) could be overestimated and Austronesian elements ignored or discounted as an anomaly. Hindu Balinese society thus still tends to be attributed with a 'hierarchical' status structure in the Dumontian sense of the word (for example, Guermonprez 1990).

The analysis of their symbolic economies has been a perennial and contentious issue in the comparative ethnology of Austronesian societies. Two major approaches to the study of status in this region may be distinguished. One has been inspired by Louis Dumont's theory of 'hierarchy', a presumably universal model of status relations in pre-modern societies based on his case study of the Indian 'caste system' (Dumont 1980, 1986). Concerns about the predictive validity and portability of his theory to societies other than India have prompted ethnographers working in Austronesian societies to develop an alternative. A new theory has been promoted by a number of researchers associated with the Comparative Austronesian Project at the Australian National University (Fox 1988, 1989; Graham 1991; Lewis 1988; McWilliam 1989; Reuter 1993; Vischer 1992; and others). The aim was to do justice to the rather different principles of status construction and distribution found to be characteristic of Austronesian societies. Their alternative theory of status relations revolves around the two key concepts of 'precedence' and 'origin'. A consensus on the formal definition of these key concepts is beginning to take shape among the proponents of this approach, especially with the publication of this volume. Allow me briefly to 
define my particular usage of the two terms in this paper and in relation to my research in Bali before moving to a contrasting discussion of 'precedence' and 'hierarchy'.

In the present case, the terms 'precedence' and 'origin' have approximate equivalents in the Balinese terms maluan (from malu, 'earlier', 'preceding') and kamulan ('origin', 'beginning'). However, these and other expressions that emphasize the flow of time as the distinguishing feature of the 'quotidian world' (sekala, from kala, 'time') are not the most central terms in discussions about social status among the Bali Aga. Like many of their neighbours, they more often evoke an all-important order of time by narrative reference to a historical migration of people through space, or by a metaphorical comparison between social history and processes of organic growth (for example, kawitan, from wit, 'tree [trunk]'; also means 'origin'). In this paper, therefore, the terms 'precedence' and 'origin' are not merely translations of local terms but are used also as descriptive and analytical constructs which seek to unpack the meaning of key metaphors in the local culture.

A social order of precedence is herein defined as a system where the status or symbolic capital of a person or group is conceptualized by reference to a temporal sequence of culturally pertinent and recursive events, such as births, marriages, migrations, or the foundation of houses and settlements. The status of specific (classes of) persons is constituted upon such a temporal sequence by their association to one of its elements. In a temporal vision of the world, the 'earlier' element is distinguished from the one which 'follows' in the stream of time and life ( $a, b, c, \ldots)$. This principle of division becomes value-laden because greater prominence is attributed to the preceding element and persons associated with it than to either immediate or more distant successors $(a>b>c \ldots)$. The valency and transitivity of the asymmetric relationships between the elements in an order of precedence thus rests upon a greater concern for the beginning of time; that is, for the 'source' or 'origin' of society and life in a sacred ancestral past. ${ }^{2}$ Where there are two distinct points of origin, two lines of precedence may be traced in parallel, each relating to a different domain of social life or different social groups within a local society.

The notion of origin is conceptually central to the construction of an order of precedence, but it does not posit an absolute value or truth. In the highlands of Bali, a person who occupies a position of proximity to a sacred origin point may enjoy a higher status than others, but life and history are continuous processes and thus the position of an individual always remains changeable. First, as new elements are added to a sequence, all earlier elements move relatively closer to the point of origin with respect to the sequence as a whole. Second, while the value-concept of origin posits the past as a sacred beginning, the historical past does not determine in any simple way how the past is actually 
viewed in the present. Origin is usually interpreted divergently within different and competing narrative histories, each of which may locate points of origin and even define the rules of reckoning precedence in different ways. Thirdly, people may actually agree that two (or more) points of origin (for example, indigenous and immigrant) are both equally relevant to complementary social status claims within different contexts. Finally, even when a single point of origin is accepted by all concerned, the value or origin naturally posits a counter value, attached to the opposite and emergent pole of the temporal sequence rather than to its beginning. The growing extremity in an event sequence is open to new opportunities, subject to contingency, and frequently associated with 'the tip (of a plant)', 'fertility', 'the new', 'the foreign' or 'the powerful stranger'. This idea of life as a self-regenerating continuity thus imposes a general limit upon the value of origin, which represents the sacred source and unity of all life. In short, concepts of origin and precedence do not dictate current social relationships by reference to a fixed, incontestable and singular past. In Bali and beyond, precedence simply assumes temporal sequence as the basic principle of people's vision and division of their society in relation to status reckoning. Given that the vision is essentially religious, Balinese are primarily concerned with the work of maintaining the sacred unity of society or of a particular group through its rituals and temples. This effort toward maintaining unity is in perpetual tension with the work of status competition, which is based on a process of division.

Bali's position is at a theoretical cross road. The people of this island are close neighbours to eastern Indonesian societies, where precedence systems were first observed, and yet their society is also a bastion of Hindu religion and Indic culture, the Southasian variant of which provided the ethnographic case material which inspired the Dumontian model of 'hierarchy'. It may therefore be profitable to reflect briefly on the relationship between precedence and hierarchy (see also Fox 1990, 1994a; Platenkamp 1990) from a Balinese perspective.

The image evoked by the word hierarchy, following its Greek etymology, is of a divine rule or government; a sacred order (from hieros: 'holy, divine, sacred' and arkhia: 'rule, government') led by a priest-leader (hierarkhes) or other human representative of divine authority. Hierarkhia thus insinuates a relationship between 'the sacred' and '(the order of) society'. Emile Durkheim later expounded upon this ancient intuition in his now classic sociology of religion. He argued that the source of the very notion of the sacred, and of transcendental or universal values associated with the sacred, lies in the individual participant's experience of society as an objective and trans-individual reality. By arguing that the experience of the social transcends the boundaries of individual consciousness, Durkheim was moving firmly towards a sociology of knowledge. Social participation indeed calls for a cognitive process which Piaget later described as 'decentring', and it thus provides the supposedly self-enveloped Ego cogito 
of a Cartesian philosophy of consciousness with both an opportunity to transcend the limits of its own existence through communion with the whole and an opportunity to define itself as a separate part in relation to other parts. Durkheim's basic insight is that a notion of the sacred arises, necessarily, from the self-transcending experience of sociality, rather than being the product of a philosophical or theological imagination. In addition, the social experience of a 'participation mystique' must also be recognized as an enactment of the basic fact of the psychic unity of humanity, and ultimately the unity of all life, which - in my view - is a natural and physiological rather than a social phenomenon.

Symbolic economies nevertheless depend on 'social values', that is, values posited upon a human proclivity to socialize and be socialized. Values based on social co-operation, following Durkheim, are inextricably linked to a notion of 'the sacred' (in the wider sociological and not necessarily theistic sense). Even the values stipulated in modern moral philosophies, though they avoid references to the sacred (in the narrower religious sense), tend to appeal to a universal notion such as 'the common good'. They thus draw upon the same universal experiential ground of human sociality as their foundation. In this broadest sense, one could argue that society is by its very nature the experiential foundation of the sacred and of universal values. In short, society is a hierarkhia which reproduces itself by inculcating a specific value-orientation into the minds of its participants, against the penultimate background of the objective unity of life.

Cross-culturally, however, a universal 'sacred' experience of sociality may be interpreted in many specific and fundamentally different ways. The particular interpretation of 'the sacred' in Indonesian societies is reflected in the concept of origin and in an associated logic of precedence. Contemporary society is regarded as the product of a history of diversification. The contingencies of this diversification history and the contested nature of contemporary social orders are not denied. Rather, the enchanted vision of society as an undisturbed experience of sacred unity and harmonious collectivity is a vision projected into the past - the moment of origin. Unlike in the Western world, where the truly harmonious and sacred society has often been a utopian projection into the future, Indonesians have tended to focus on a collectively shared (and thus sacred) time of origin, the one root from which the many branches of society have grown.

It may be objected that the vision of the sacred for contemporary Indonesians is also prominently defined by one or another of the world's great religious traditions, in the Balinese case by Hinduism. However, while they may be required to profess publicly to one of the constitutionally-recognized world religions, many Indonesians simultaneously maintain an underlying concern for 
origins, in keeping with concepts and practices predating the arrival of Hindu-Buddhism, Islam and Christianity.

A common form of 'religious' (agama) or 'customary' (adat) practice in Indonesia is the 'worship' or rather 'acknowledgment' of deified ancestors associated with particular social groups and simultaneously with particular localities; with temples, cemeteries and other landmarks in a sacred topography. The names of these ancestors or places (or both) are often recorded in 'myths' or historical narratives that describe the creation of the world and the origin of society. The role of ancestry and topography in defining 'sacred origins' shall be discussed in detail later, using Balinese case material. For now, it is sufficient to note that this specific interpretation of the sacred generates a temporal and process-oriented system of social valorization. This stands in stark contrast to the substance-oriented notion of the sacred which has been reported in different studies of Indian society, and for which Dumont postulated 'purity' as the paramount value for the purpose of drawing status distinctions.

Although the notion of origin, as a specific interpretation of the sacred, is central to a specific form of hierarkhia in Indonesian societies, this does not necessarily imply that it constitutes a paramount value in the Dumontian sense. To begin with, Dumont's notion of hierarchy - as a social order based upon a single all-encompassing (religious) value — is a totalizing interpretation of Durkheim's notion of 'the sacred'. Durkheim's basic idea of the socio-genesis of the sacred and of social values may be correct. But although society generates and reproduces itself through an enchanting experience of sociality, it also generates the disenchanting experience of a multitude of separate individuals with often incommensurable positions and interests. ${ }^{3}$ Social experience is characterised by anarkhia as well as hierarkhia.

Losing sight of specific historical and dialectic social processes, through which the order of a society is only ever enacted and reproduced in a partial and imperfect manner, Dumont focuses instead on an evolutionary social history following the trajectory of a universal Hegelian dialectic. His is a history leading from a pre-modern, unified and hierarchical to a modern, fragmented and egalitarian form of society. Adopting this evolutionary perspective, Dumont allows for a plurality of values only in the context of a modern society. His distinction between modern (individualistic) and pre-modern (collectivity-oriented) thinking also resonates with aspects of Max Weber's theory of modernity, who suggested that the singular value-orientation and sacred wholeness of hierarchical societies apparently became fragmented into a kaleidoscope of separate values and value spheres. ${ }^{4}$ This argument denies in modern subjects the ability to experience sociality as an ontological ground from which universal values may be derived, as well as denying so-called pre-modern subjects the ability to acknowledge a plurality of social contexts and a diversity 
of positioned interests. Dumont's support for these unfortunate marriages, between modernity and value-fragmentation and between hierarchy and singular values, has earned him much criticism even on his home ground India.

The problem with a singular value theory of hierarkhia, of the relationship between the sacred totality of society and the values governing its status economy, is that the untold diversity of specific social categories in India (for example, varna, 'colours'), for example, cannot be logically predicted on the basis of a bland and colourless value such as 'purity'. Undifferentiated by its very nature, this concept is translated into a model of social differentiation by an interpretation of resemblances between a zero-state of 'purity' and the relative degree of pollution of different categories of persons or objects. A cultural system of hierarchization is thus always the result of a process of value exegesis, a struggle of representation driven by participants' experience of society as anarkhia. The transcendental unity of a single and featureless value, such as 'purity' or 'origin', must be shattered or 'fragmented' before it can provide a practical model for evaluating the social and natural world in all its complexity. The sacred as such is not yet a principle of social classification. It acquires relevance, in the conceptual and practical sense, through a collective labour of interpretation, no matter whether the sacred is conceived as 'origin', 'purity' or 'reason'. Only then can sacredness be attributed to persons and give rise to an order of precedence, a caste system, or a modern state bureaucracy. In my understanding of Indian ethnography, for example, the exegesis of the sacred as a state of purity relies upon a complex interpretive convention, a theory of substance and contagion, and on associated practices of segregation (cf. Marriott 1976). To describe Indian hierarkhia as the product of a single value is a tautology, in the sense that purity (a state of being without distinct properties) is as yet little more than a synonym for 'the sacred' (a society without individuals, individual interests or differences). Mistaking 'purity' as a full interpretation of the sacred is to ignore the enormous interpretive effort which separates the nameless 'purity' of the sacred, for example, from the purity of a substance such as clarified butter (ghee) or from the purity of a Brahmin.

The multiplicity and messiness of values 'in action' is less apparent when viewed across a temporal, cultural or presumed evolutionary distance than it is from the position of a local participant. It is all the more important that ethnographers approach the study of symbolic economies through intimate observation of local relationship practices and local discourses on human relatedness in all their complexity. It is easy to become enchanted by the simplicity of a transcendental value and its power to totally 'explain' a social order. However, it is not the task of social science to reproduce the totalizing attempts of local discourses at the level of analysis, let alone to create a totalizing vision of a state of affairs which the participants themselves recognize as a momentary state in a dynamic sequence of events. With these cautions in mind, 
let me proceed towards an ethnographic description of how status is constructed and distributed in the highlands of Bali.

\section{The Economy of Status Among Mountain Balinese}

From a Pan-Balinese perspective, the Bali Aga or 'Mountain Balinese' are recognized as a culturally distinct and indigenous ethnic minority. Most of their fellow Balinese in the southern lowlands hold them to be the island's original inhabitants. They are frequently associated with a distant past portrayed at once as a mythical time of sacred origin and as an uncivilized age. Other Balinese trace their origin to noble warriors from the Hindu Javanese kingdom of Majapahit; royal outsiders who presumably invaded the island in the fourteenth century and subsequently reconstructed Bali's (pre-colonial) socio-political order. From that time onward the Bali Aga lost all claims to political power, however, they managed to retain a number of important ritual privileges. Tens of thousands of pilgrims from the coastal regions continue to attend the annual festivals of Pura Pucak Penulisan, Balingkang and Batur and other ancient highland temples (pura) that remain firmly in Bali Aga hands. The ceremonies secure the fertility of the island's agricultural land as well as protecting and coordinating the life-giving flow of irrigation water (Lansing 1987, 1991). Even the heirs of the Majapahit invaders, the royal families of Bali's southern courts, will regularly attend these temple festivals.

In sum, the royal courts of southern Bali and their followers represent the political authority of Majapahit, a 'new' and external point of origin, while the Bali Aga, at least in some contexts, wield ritual authority as representatives of an ancient and internal point of origin; as the people whose ancestors first cleared and still protect the land. Political power and ritual authority in Bali are thus constructed upon distinct but complementary value scales, even though both of prominently evoke a notion of origin (external or internal). The institutionalized duality of 'newcomer' and 'indigenous' authority in Bali (Reuter 1999) is a variation upon a common cultural theme among Austronesian-speaking societies (see Fox 1994b).

Although the distinction between political and ritual authority may have become institutionalized in Bali, the distribution of symbolic resources between the two parties is the outcome of a specific political history, a complex and emergent arrangement that remains forever subject to contestation and change. That the Bali Aga have retained a significant stake in the symbolic economy of Bali over the course of this long historical struggle is not explainable by reference to a generic cultural theme, whereby the ritual precedence of indigenous people ought to respected by newcomers. Nor is it an accident. Research has shown that the Bali Aga are organized not simply in odd and inward-looking village communities, as was commonly believed, but in regional and inter-connected ritual alliance networks (Reuter 1998). These institution provided the social technology that has allowed them to resist cultural absorption. Regional research 
has also revealed that all Bali Aga villages share a common and typical pattern of local organization (Reuter 1996). Each community is governed by a complex rank order of elders. ${ }^{5}$

The two following ethnographic sections describe the ranking of villages within 'regional ritual domains' (banua) and the ranking of elders within the local 'councils' (ulu apad) of individual 'villages' (desa). It is argued that regional and local orders of precedence are both structured by a value orientation focused on a historical and process-oriented concept of sacredness, namely, on the idea of a sacred origin and a subsequent process of expansion.

\section{Banua: Origin and Precedence in Regional Ritual Domains}

In the highlands of Bali, a regional ritual alliance of villages is referred to as a banua. The meaning of this term is complex and variable. From a functional perspective banua may appear to be networks of ritual and political co-operation. ${ }^{6}$ The participants themselves, however, prefer to phrase their relationships in terms of a shared ritual obligation towards a regional temple, a sacred place of origin and emblem of their sacred unity. The various relationships of member villages to the central temple, and to the origin village in which it is located, are defined by the historical order of their foundation. The history of the domain is commemorated by tracing the historical (or fictional) journey of the ancestors from the point of origin to the subsidiary member villages backwards, in a ritual journey of returning to the point of origin. Narrative origin histories and associated ritual enactments emphasize that each banua is a specific order of precedence, the unique product of a historical progression from an initial state of unity to a contemporary state of differentiation.

The most accurate and succinct way to convey the meaning of the concept banua is through the notion of a 'ritual domain'. The idea of a 'domain' captures the territorial connotations of banua, not only in Balinese but in many related languages. Reflexes of the Proto-Malayo-Polynesian reconstruction *banua found in many contemporary languages of this language group are generally used to convey the idea of a 'land', 'territory', 'settlement' or 'village' (Fox 1993:12; Reuter 1998:68). For example, in Javanese, wanua or wanwa connotes a 'village territory' (Supomo 1995:295).

The various implications of 'participating in a banua' (mabanua) are expressed in Balinese by means of composite terms: desa banua - the oldest 'village' (desa) of a 'domain' heading a group of subsidiary settlements; gebog banua - 'a set' (gebog) of villages which recognize a common origin and ritual responsibility; pura banua - the principal 'temple' (pura) of a domain which marks its point of origin, or keraman banua, the congregation of the 'heads of households' (from rama, 'father') who finance and participate in the festivals of a banua temple. The terms 'banua' and 'gebog' carry similar meanings, except that banua is more 
suggestive of the domain as a space, whereas gebog refers to the inhabitants of a set of villages who are the foremost supporters of the domain's principal temple. Often the wider membership of a banua includes villages which are not part of this set of core supporters, but who still consider themselves entitled and obliged to participate in and contribute to the temple's ritual events on a regular basis.

Most informants portrayed their ritual participation in a banua as the fulfilment of their role as a specific part within an 'organic' whole. This idea of society as a 'body' finds expression in the symbolism of sacrifice, for the ritual order of a banua is also a sacrificial order. An animal victim, most often a buffalo, is sacrificed at every major festival of a banua temple. Its body symbolically represents the domain as a composite whole. The buffalo is slaughtered and dissected by ritual specialists. An assortment of specific bones and body parts is carved from the carcass in order to structurally reconstitute and symbolically 'resurrect' (wangun urip) the victim. The image of 'incorporation', of elements in a social whole or 'body' faithfully performing their specific part in the orchestra of collective ritual practices, does away with the conflicting symbolic interests that may create competition and sometimes even a permanent split among the different 'members' of a domain. Nevertheless, interviews with participants revealed that they are well aware of a disjuncture between this enchanted ideal of unity and the reality of status contestation within their domains. $^{7}$

Occasional conflicts among the members villages of a banua tend to be focused on questions of ritual precedence. Most banua or, more precisely, their regional temples (pura banua) are controlled by only one of the participating communities. Most commonly, the village in whose territory the banua temple is located will claim a position of ritual precedence through explicit reference to the domain's origin history. The ritual specialists who conduct all ceremonies at a banua temple are recruited from among the priest-leaders of its origin village, though there is one case (Pura Indrakila) where priest-leaders from several communities rotate the status of 'ritual and organizational leader' (pangamong or pangempon). ${ }^{8}$ These local terms are more suggestive of extraordinary duties than of superior rights. Nevertheless, questions of ritual precedence and relative status are of crucial importance in all banua. Narrative or ritually enacted status claims can be and frequently are subjected to contestation and refutation.

Their common designation 'banua' is a reflection of the conceptual and organizational principles shared among the numerous ritual domains of the highlands (see Figure 1). Nevertheless, each one of them also forms a separate and historically unique symbolic economy. Of particular importance are variations in how asymmetric status relationships between older and newer villages in a banua are conceived and articulated. These variations shape the particular status narrative and distribution pattern within a domain, even though 
the basic principles of status construction and distribution always evoke notions of origin and precedence. Some examples of different types of banua may help to illustrate the range and scope of these variations.

The simplest type of banua is a small cluster of villages, one of which is regarded as the oldest and the origin of the others (desa banua). A mytho-historical relationship between the villages is enacted through reciprocal 'visits' during the festivals of village temples. The precedence status of the origin village is made obvious by distinguishing two types of 'visit'. For example, the village deity of the source village Bayung Gede is regarded as the parent of the deities of its branch villages. The parental gods sometimes 'go forth' (lunga) to visit their 'children', but more often the gods of the branch villages 'return home' (mulih) to visit their 'parent(s)'. Occasions for these ritual visits are the festivals of local temples such as a Pura Bale Agung ('temple of the great pavilion') or a Pura Puseh ('navel temple'). The 'going' and 'returning' of related ancestor deities and their human descendants combines the idioms of topography and ancestry. It conveys the idea of predecessors and successors ranked in a spatio-temporal order of precedence.

In a more human interpretation of history, the communities within small banua of this type regard themselves as linked by a series of ancestral emigrations. The idea of a common ancestry is conveyed through an idiom of place, given that there is no genealogical knowledge of sufficient depth to retrace the distant relationships between the founders of the participating villages. For example, many of the subsidiary villages of Bayung Gede are said to have grown from clusters of temporary dwellings (pondok) in garden plots too far removed from the source village for their occupants to return daily after completing their work. Penglipura is one of the downstream pondokan of the source village Bayung Gede which have evolved into separate village communities (desa adat) with their own sets of temples. The people of Penglipuran still pay ceremonial visits (mabanua) to the source village during major festivities, and are obliged to bring collective prestations as a village for the gods of Bayung Gede. 'Village-level prestations' (atos desa) constitute a key marker of a relationship between villages in a banua context.

Atos desa contributions are not explicitly recognized as exchanges between ranked status groups. They are exchanges in a rank order of divine beings in which humans participate as ritual facilitators. This displacement of human status relationships onto invisible agents successfully navigates some of the conflicts of interest among the partners in a regional ritual alliance.

Even recent immigrants within a branch village who have a separate ancestry must partake in rituals commemorating the deified founders of that village, and of the domain to which it belongs. In contrast to more exclusive notion of kin group affiliation by descent, a man's reliance on village land is sufficient grounds 
to demand his participation in village ritual. Most residents of branch villages, however, do claim that they are related to the source village by ties of common ancestry, particularly the village founder group. The visits to the source village serve in part as a mechanism to commemorate that the ancestry of the founder group is also the ancestry of the village, and to reinforce their privileged status or political power within the branch village. Nevertheless, mabanua is an activity involving villages (rather than descent groups) and generally strengthens their internal unity. ${ }^{9}$

There is another type of banua wherein the internal precedence ranking between villages is not as distinctly asymmetric. The common point of origin is no longer embodied and thus claimed by a living community, but is projected into the past. An example is the banua around Pura Tebenan, a forest temple located near the village of Manikliyu. The original village of Tebenan is said to have been destroyed in ancient times following a dispute and civil war. The survivors were scattered in the eight cardinal directions and founded eight new villages: Ulian, Gunung Bau, Bunutin, Langahan, Pausan, Bukhi, Bayung Cerik and Manikliyu, the one closest to the old Tebenan. Eventually the old temple of Tebenan was rebuilt following an initiative from Manikliyu. Ever since, the eight villages have gathered there for joint ceremonies to honour their common ancestors. The origin narrative establishes Manikliyu's role as honorary ritual leaders of the domain. However, in relation to the abandoned village of origin their status is merely that of primes inter pares. Note that Pura Tebenan no longer falls within the category of a village temple.

A third type of banua is based not on common ancestry but on patron-client relationships among villages with multiple ancestral origins. Most banua include newcomers as part of the population of their individual member villages. In these banua, however, the very founders of subsidiary villages within the domain of a large original village are believed to have been immigrants with no prior connection to the founders of the domain. The founder group in the original village claim that their ancestors were the first settlers who cleared the forest. They are the wedan, 'the people of the trunk' (from tuwed 'lower trunk, base or stump of a tree'). Other settlements were founded on vacant land within the territory of this large original village by later arrivals or pendonan, the "people of the leaf' (from don 'leaf'). ${ }^{10}$ These newer settlements eventually developed into separate but dependent villages.

Selulung is the origin village of such a banua. The origin narratives of this domain describe how newcomers arrived, 'requested land' (nunas tanah) from the legendary 'Jero Pasek' of Selulung (still the title for the head of the founders' kin group), and established new settlements. Sometimes the relationship of land exchange was augmented by an affinal exchange, in which case the land was classified as a marriage gift (tadtadan, lit. 'things carried' or 'brought' by the 
bride). Uxorilocal newcomer grooms usually became founders of new branches to the local bride's paramount ancestral origin temple (pura kawitan, from wit, 'tree', 'origin'). However, all newcomer villages pay homage to the deified spirits of the ancestral founders of the domain at the main village-level temple of Selulung. The fact that some of them have immigrant clients or pondokan of their own, with secondary ritual obligations, creates a rank order of precedence within the domain.

Those who seek to be admitted into a status group are generally expected to conform to the behavioural norms and way of life of that group. A status group cannot be maintained without cultivating a sense of homogeneity, for it is the similarity displayed by its members which distinguishes it from others. In this type of banua, however, a sense of common tradition has to be maintained in the absence of a common ancestry and cultural heritage. This is achieved by stipulating that all client villages had to perform rituals (even in their local village temples) in conformity with the 'traditions' (adat) of the first settlers of the domain (that is, of the origin village) and abandon the traditions they may have had before their arrival.

At the same time, a degree of internal stratification can be maintained in a status group by restricting access to knowledge of more esoteric norms and symbolic capital to its core members. For example, informants in Selulung's client villages tended to have a sketchy knowledge of the domain's origin narratives and would frequently refer me to elders in the core village. Conformity to the same traditions may identify the members of this domain, but it does not identify them as equals in knowledge or status.

The client villages of Selulung have repeatedly attempted to gain ritual independence for themselves. In the absence of a shared ancestry, obligations to the founding ancestors of the core village are potentially contestable, provided that the clients are able to construct their own and separate origin as the beginning of 'relevant history'. Status distribution is problematic in all types of banua. There is usually sufficient 'historical uncertainty' to allow for a reinterpretation of the origin narratives and a reorganization of associated ritual practices. $^{11}$

Finally, there are banua centred upon 'summit temples' (pura pucak) such as Pura Pucak Penulisan. These temples represent a more abstract idea of shared identity. At some time in Balinese history, possibly under the influence of early pre-Majapahit Hindu kingdoms, ritual alliances developed into institutions which transcended localized notions of origin. The larger banua temples have likewise transcended the character of a village temple. The status of these ritual centres is linked to narratives about distant historical and mythical events; about the first kingdoms that flourished in the highlands and about the time when paramount creator deities fashioned the world. Creation (pangawit) is believed 
to be an on-going process of growth rather than a fait accompli. A continuous and harmonious relationship among the natural, human and heavenly worlds needs to be actively maintained through a ritual process. Large pura banua are the sites of ritual for the revitalization of an entire realm and may have tens of thousands of supporters. In some contexts their deities may still be depicted as local ancestors, but in others they are portrayed as the creators and guardians of the entire island of Bali.

The festivals of large pura banua are of such a grand scale that they cannot be financed from the resources of one village alone. Instead of one village acting as the hosts who entertain and feed people from visiting villages, these festivals are organized, performed and paid for collectively by all core members of the (gebog) banua. Although all large pura banua are maintained by such a fluctuating core membership, this does not preclude additional villages or individual worshippers from presenting atos desa or personal offerings (nyasah).

The largest and most ancient domain of the highlands is that of Pura Pucak Penulisan, a temple located in the village of Sukawana. Like other domains of similar magnitude, the Penulisan network incorporates several smaller alliances such as the banua of Pura Tebenan. It is generally the case that large banua have major subsidiary lines of precedence beneath the supreme point of origin, embodied in an ultimate origin village. For example, Penulisan's core support group, figuratively referred to as 'the set of 800 [households]' (gebog domas), is divided into four 'sets of 200' (gebog satak). One of them is the above-mentioned group around the origin village Selulung.

The connections radiating from the centres of contemporary banua to their member villages, together with secondary links between the centres, create a pattern of staggering complexity (see Reuter 2002a for a more detailed description of these networks). The most important individual networks are represented in Figure 1. The diagram shows a pattern of ritual ties between villages which more or less adhere to 'Bali Aga traditions'. This is not to imply that the principles of regional ritual alliance which have been outlined above apply only to this part of Bali. Some southern Balinese temple networks employ similar concepts, narratives and ritual practices for their constitution and maintenance. ${ }^{12}$ 


\section{Figure 1. Ritual networks in the highlands of Bali}

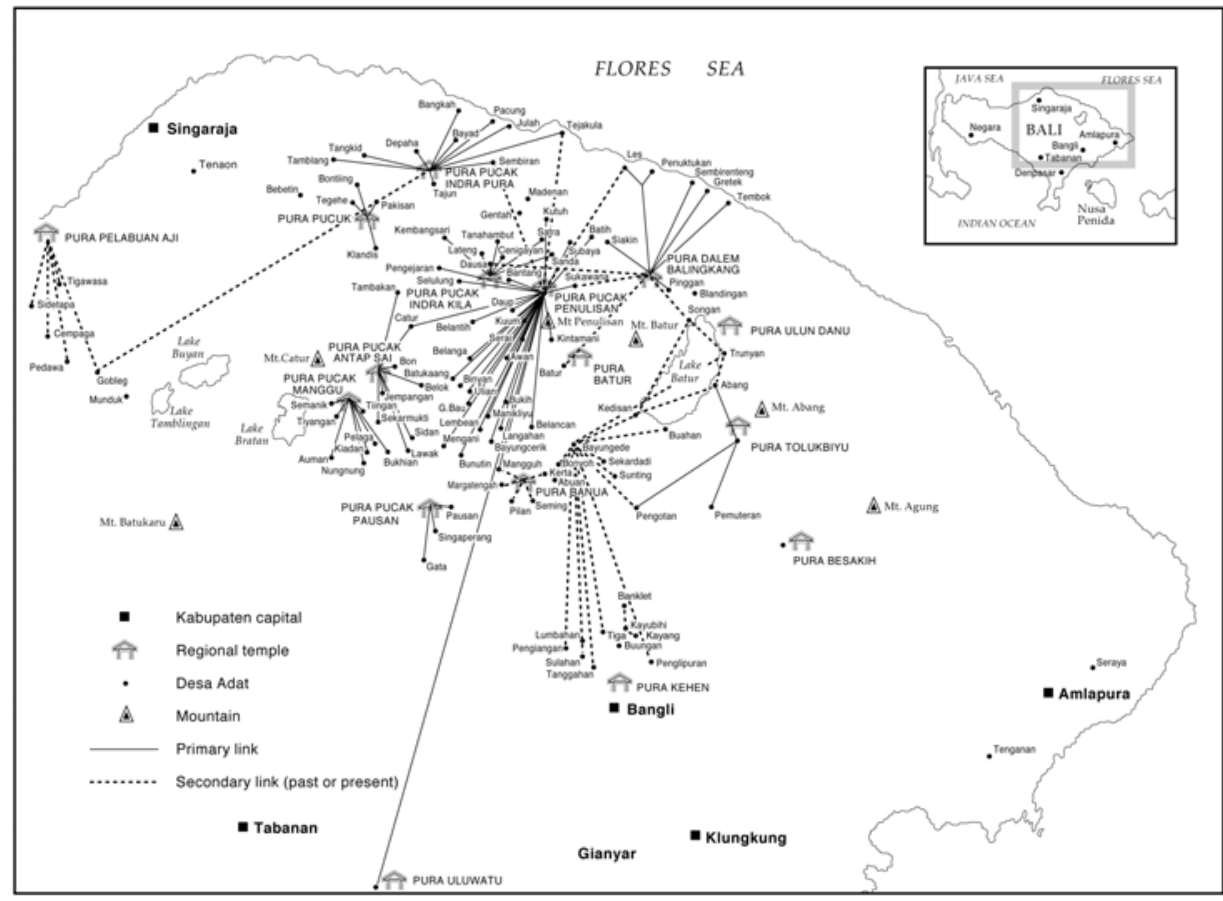

The general rationale of banua organization revolves around the two related key concepts of 'origin' (kamulan) and 'precedence' (maluan). The status of a village is indexed upon its time of foundation in relation to other foundation events. The temporal sequence of village foundations represents a chain of events tied to specific localities, and the emblems of these events are the temples which signal the birth of a new village. The relationship between villages closer to or further removed from the source is not one based upon a notion of logical encompassment or on a code of substance and purity. A local idiom of botanical metaphors describe a process of growth, a historical flow of life (kauripan) from the 'old trunk' to the 'new leaves', reciprocated by a flow of ritual prestations from the people of the present to their ancestors in the past, and extended forward through human procreation and the unfolding of history. The part-whole relationships in this model of society are not based on binary oppositions. Trunk and tip represent shifting polarities in a continuous expanding historical sequence resembling the growth process of a plant. 


\section{Desa Ulu Apad: A Ritual Community and its Ceremonial Assembly}

It is paradigmatic of Balinese culture to find temples at the centre of various social networks. What distinguishes the banua temples of the highlands is that their members are desa (Sanskrit, 'village/place') whose inhabitants nearly always belong to several kin groups. Banua and desa are indeed closely connected and similarly conceived institutions. Both are ritual communities tied to a bounded territory in so far as they share a common obligation to the ancestral guardian deities of this land, and to their temples. The leaders of a banua have no mandate to interfere in the political or ritual affairs of member villages. The desa-banua relationship is best characterized as one of mutual support. A sense of unity is fostered among the internal factions of a desa adat ('customary village') by the fact that they must co-operate as a status group in relation to other villages in the domain. Interconnected highland domains also generate a regional sense of common Bali Aga identity in relation to the outside world. In turn, the banua relies for its very existence upon a voluntary co-operation among otherwise autonomous villages.

Desa Sukawana may serve herein as an exemplary case of how Bali Aga villages are organized. The highest ranking elders of Sukawana act as priest-leaders at Pura Penulisan on behalf of what is the largest banua in the highlands of Bali. By virtue of their status as custodians of this oldest and most significant ritual centre, Sukawana's traditions provide a local standard of authenticity.

Sukawana is a named village with a distinct territory, leadership and tradition. However, it is by no means a homogeneous community. A complex classificatory schema defines each person's status and role in relation to the village as a whole. A first criterion of status distinction is focused on a person's relationship to the land. The desa adat includes a considerable number of landless share-croppers, a group referred to as desa giringan ('aslant', that is, 'leaning onto the desa adat proper'). Share-croppers are classed as newcomers and their status is very marginal. However, given that they are permanent residents who partake in the produce of the land, they have a duty to contribute to the ritual life of the desa adat. $^{13}$ Share-croppers can be called upon for unpaid ritual labour services (ngayah) and must pay a quarter of a normal household share towards the 'ritual expenses' (peturunan) of the village. They are excluded from formal decision-making processes and rarely have the wealth to exert an indirect influence on village affairs.

The few newcomers who actually do own agricultural land in Sukawana must join the village assembly proper, the desa ulu apad. While newcomers thus are permitted to buy land, and are subsequently allowed and indeed required to join the desa ulu apad, they are barred from rising above the most basic level of 
rank therein (saya tilem, the group of junior members who serve the elders at new moon meetings). For this reason, separate membership lists must be kept; one for the descendants of Sukawana' founders (wed desa) and another for newcomers (pendonan desa). The small group of land-owning newcomers is referred to as desa pamugbug (from bugbug, a 'pile' or 'heap'), alluding to the fact that the ceremonial food portions for these unranked members of the ulu apad are piled up in an amorphous heap during temple feasts rather than laid out in order of rank.

The drawing of distinctions between share-croppers and land-owners, and between newcomers and locals, shows that a person's duties and rights in the ritual life of the desa adat are indexed upon their practical and historical involvement with the land. As a defined space, the desa adat is a highly inclusive category, so much so that even a person passing through its territory is for that time subject to its local customary laws. But in parallel to this power of inclusion a strategy of exclusion operates, whereby descendants of village founders enjoy ritual (and political) precedence over recent newcomers. Newcomers are prevented from taking control of the desa adat by denying them access to the higher ranks of the ulu apad or 'council of elders'. Some such form of stratification is found in most Bali Aga villages, though the specific distributions of rights and duties may vary. For example, in many other villages the core assembly members are also the people who have exclusive access to village-owned land (tanah ayahan desa or $A Y D S)^{14}$

At the time of research the village assembly (desa ulu apad) of Sukawana had 740 male members. Each male member of the assembly must be married. He thus represents a household (kuren, 'hearth') — the most basic social and corporate unit of Bali Aga society. A man becomes a member of the desa ulu apad after the third stage of the marriage ritual (masakapan) has been completed. The time of entry of a man's name into the village register permanently determines his relative rank in relation to others who joined earlier or later. The rank order in 'Bali Aga' villages thus is not, strictly speaking, a gerontocracy, though in general the time of marriage may correlate with chronological age. The basic principle is a ranking in order of precedence among households (married couples) rather than individuals. Nowadays the all-important register of members is kept in a notebook, which is awkward due to the constant changes in the ranks due to retirements. Formerly the rank order of members was recorded with a device consisting of a circular string to which many smaller and some larger bamboo tags were attached. The smaller tags carried the names of members and one was removed when the person retired. The larger tags were moveable, indicating who was due to fulfil a rotated duty at any given time. ${ }^{15}$

The rank-order of the assembly is expressed visually in the seating order of men during customary meetings (sangkepan adat) held in the ceremonial village 
'longhouse' (bale lantang). Ceremonial longhouses are located in the Pura Bale Agung and in other village temples. ${ }^{16}$ In Sukawana the elders (in smaller villages all assembly members) meet on each full and new moon (purnama/tilem) in order to discuss village matters and partake in a ritual meal. A formal seating order is observed (Figure 2). The food portions are laid out in a long double row and are taken in order of rank. The highest ranking members or 'elders' receive an honorific title and fulfil the most central ritual tasks. They sit at the upper end (ulu) of the bale lantang, which is pointing 'towards the mountain' (kaja) and the shrines of the village ancestors. Lower ranking members sit closer to the lower end (teben) pointing 'towards the sea' (kelod) and the realm of demonic spirits. In most villages, but not in Sukawana, the lowest ranking person also has a specific title (pider/pamuit) and function.

Figure 2. Rank order of elders in Sukawana (seating order during ritual gatherings at new moon)

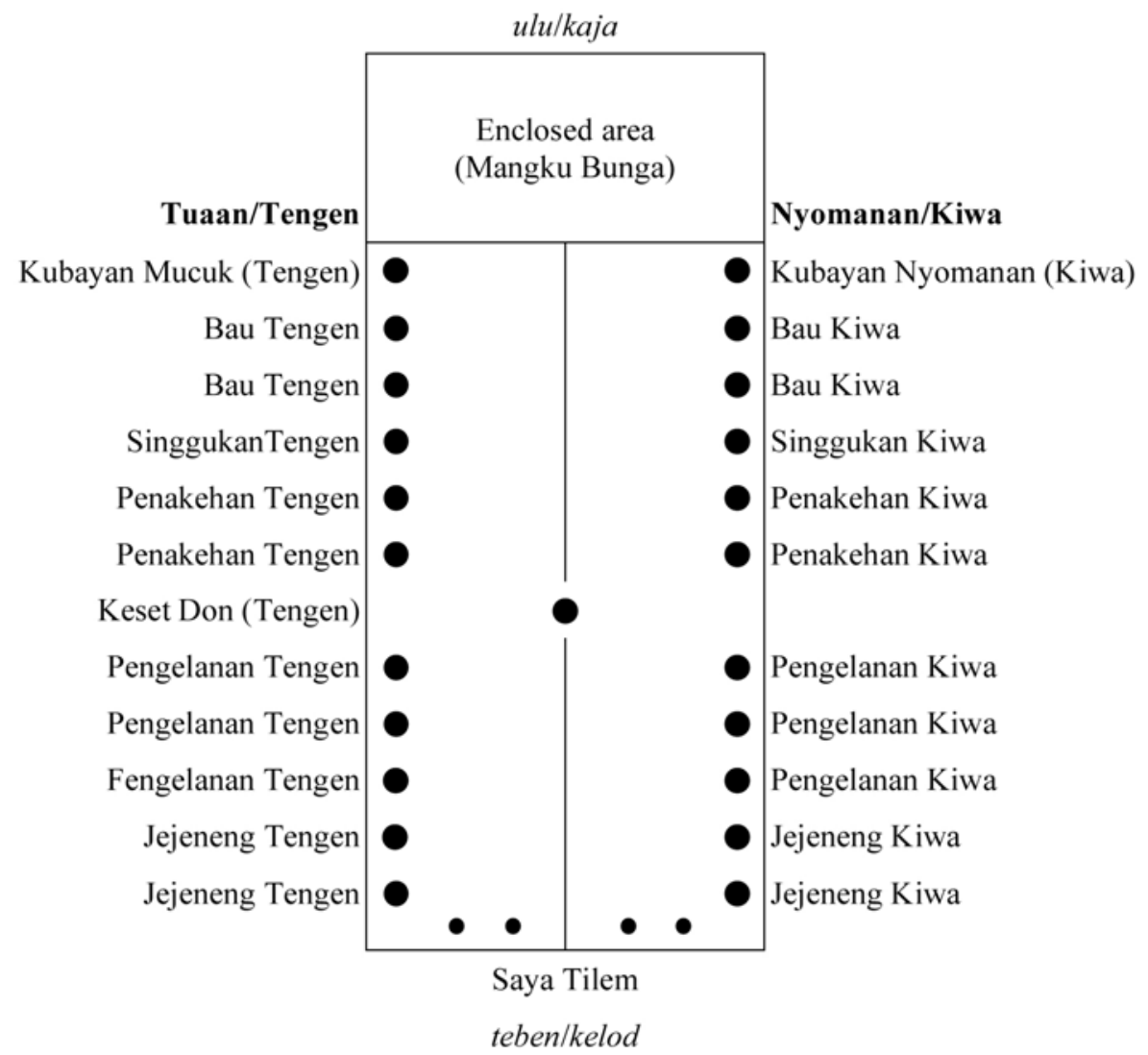


The term ulu apad (or dulu dapuh in some villages) means 'the steps to the top [of the bale lantang]', from ulu, 'at the top/head'; and apad, 'the planks of wood between two posts which divide the longhouse into sections' or dapuh, 'the two long planks at the sides of the longhouse platform on which the elders sit'. It thereby refers to a process of ranking and succession common to all Bali Aga villages. A full member (keraman) may progress towards higher rank by gradually moving from the bottommost to the topmost position in the village assembly. He rises one step upwards each time a position higher than his own (on his side) is vacated by the death or retirement of a higher ranking member.

The membership of the ulu apad is further divided into two 'sides' (sibak) or ceremonial moieties of approximately equal size: those who sit on the left side (sibak kiwa) and those who sit on the right side (sibak tengen). ${ }^{17}$ In Sukawana a man belongs to the same sibak as his father. The members of the right side are also referred to as Tuaan (from tua, 'old[er]') and those of the left as Nyomanan (from nyom, 'young[er]', or nyoman, 'third-born child'). By implication the Tuaan are symbolically 'male' (right), the Nyomanan, 'female' (left). ${ }^{18}$ Because a Sukawana man belongs to the moiety and ancestral 'origin temple' (sanggah kamulan) of his father, this is not merely a symbolic but a social division of the village population into two groups. The relationship between the two sibak is a complicated matter to which I shall return later. However, there is no rule prescribing or prohibiting marriage between sibak (a slight statistical trend towards sibak endogamy in this case is merely coincidental to a preference for sanggah endogamy).

The top-ranking elders of the assembly form the ulu apad proper; that is, the leading body of the desa ulu apad. In the council of Sukawana there are 23 titled positions. Each named rank is associated with a specific ritual function, which is fulfilled by whoever holds that rank at a given time. ${ }^{19}$ The required knowledge and skills are learned gradually. Each person observes and is instructed by those who precede him (maluan) and passes on their own knowledge to those who succeed him (pungkuran). The slow movement to positions of increasing responsibility involves such a thorough process of training that there is rarely any incompetence. The basic philosophy of the ulu apad system is that each person has a duty and a right to carry increasing responsibility and authority as they progress through a number of life stages. The responsibility and authority of elders in Sukawana is not confined to a ritual context. Though contentious community issues are discussed openly, the head elders have the final word in any decision.

A person's involvement with the desa adat does not begin with marriage. The status increase associated with having founded one's own household is as much the end as it is the beginning of a process. While marriage initiates a long upward progression towards greater ritual involvement as an adult, it also marks 
the end of a process of decline in ritual involvement, from childhood to puberty and marriage. In general, a person's ritual involvement in the desa adat is thus negatively correlated to their fluctuating involvement in worldly and sexual activity throughout their life.

During early childhood and until the awakening of a sexual awareness, children fulfil an essential role in the ritual life of Sukawana (and other Bali Aga villages). All children join organizations for boys (sekaa teruna) and girls (sekaa daa). The duties of daa relate to rituals of fertility. The arm movements in the rejang daa dance, for example, emulate the sowing of rice. The teruna are involved in activities displaying or requiring youthful vigour and a spirit of competitiveness, such as spear dances (baris tumbag). In addition, Sukawana has a special group of eight very young boys referred to as mangku bunga ('flower priests'). They are selected by the elders at an early age and are the only persons permitted to touch the sacred relics of Pura Penulisan. Surprising though it may seem in an apparent gerontocracy, they symbolically rank above the elders, and are accordingly seated in the top-most, boxed-in section of the ceremonial longhouse. Similar to initiated priest-leaders (the six top ranking elders), they may not cut their hair and must wear the traditional hand-woven black and white sarong (kamben kotak geles) and white head-cloth (udeng putih) which signify priesthood.

Membership in the desa ulu apad is limited to the duration of a person's married life, and relative rank is determined by the time of marriage. This focus on marriage as a marker of status within the desa adat is reflected in ritual practice. Marriage choice may be a matter in which the desa adat interferes only in so far as it does not sanction certain forms of marriage. However, a marriage is not valid unless it has been witnessed and confirmed by the elders. In most Bali Aga villages there is no exchange of bride-price between the families involved. And yet, taking Sukawana as an example, the husband must purchase and ritually offer two pigs to the desa adat, one for himself and one for his bride. This 'payment' to the village is called tumbakan (from tumbak 'spear') in Sukawana, and some say it used to be a payment for releasing a young man from military duty at the time of marriage. ${ }^{20}$ In other villages the payment is called bakatan ('to obtain s.th.', 'to receive s.th. back') and is said to compensate the village and the ancestors for releasing a girl from her ritual duties as a 'village virgin' (daa desa). ${ }^{21}$ This payment signals that the institution of the desa has to some degree appropriated 'marriage' from the domain of kinship and elevated it to a global principle of ranking. Among kin, the rank of households is signified by the position of their individual dwellings within an uphill-downhill oriented house row (or two parallel rows). This arrangement of the houses of kin in a houseyard already anticipates the structure of the ulu apad (see Reuter 2002b). 
There are a number of special services and initiation rituals, the performance of which separates people at different rank levels in the ulu apad. The most extravagant ceremony (mapurohita) marks a person's transformation into a priest-leader (Jero Bau). Following that, there is one final rite which signifies the closure of the cycle of life. When a Jero Bau replaces a retiring Kubayan, he is installed as the new head elder in a ceremony called mayah piteh, 'to pay for turning around'. The candidate in this ritual turns around for the first time, from facing up-hill ( $u l u$ ) like all other members of the assembly to facing teben. His former seat was on the tip (muncuk) of the long dapuh plank pointing kaja, to which he gradually advanced over the years of his membership, beginning at its base (bongkol). But from now on he will sit on the adjacent tip of the shorter dapuh, the tip of which points kelod. ${ }^{22}$ He is now separated only by a thin wall from the mangku bunga, the emblem of the sacredness of youth. Both are in a liminal state at the boundary between life and afterlife, a boundary which for the old is death as for the young it is birth.

The architecture of Sukawana's bale lantang presents the partial image of a circle. Figure 3 illustrates how the transition to the highest rank is expressed in its design. Whenever a bale lantang is built, great care is taken to mark the tip-end and base-end of a pillar or plank as it is cut from a tree. Generally the tip-end (muncuk) of a piece of timber is fitted to a building so that it points to the sky (or uphill) as it did when it was still part of the tree. In this case, however, there are two notable inversions. First, the two upper-most pillars at the enclosure for the mangku bunga are placed with the tip pointing to the ground rather than the sky. Second, the upper, short dapuh on both sides have their tips pointing down-hill rather than up-hill (like the lower, long dapuh). This arrangement is said to emulate a circle (windu), the eternal cycle of life which unfolds in the visible world of living and time-bound beings (sekala, as opposed to niskala, 'sacred, time-less').

Retirement from the desa adat occurs at the end of a person's active married life. When a man's last-born child (panak) or first-born grandchild (cucu) - male or female - has married, he and his wife cease to be members of the desa adat (baki, 'to reach menopause'). Likewise, if either of the couple die, the survivor must also retire (balu, 'to be widowed'). The average age of retirement in Sukawana lies at about 50 years, while the approximate age at the time of becoming the lowest/highest-ranking elder lies around 45/60 years respectively. This means that while any member of the desa adat can become a ritual leader in principle, most people retire before reaching the rank of Kubayan. This system of retirement adds an element of chance or, as locals would say, 'divine providence' to what would otherwise be a predictable process of succession. The process of retirement can be and sometimes is manipulated. For example, an elder may hold on to his position by re-marrying, or by adopting another child. 
Figure 3. Cosmology of the ceremonial longhouse (Sukawana)

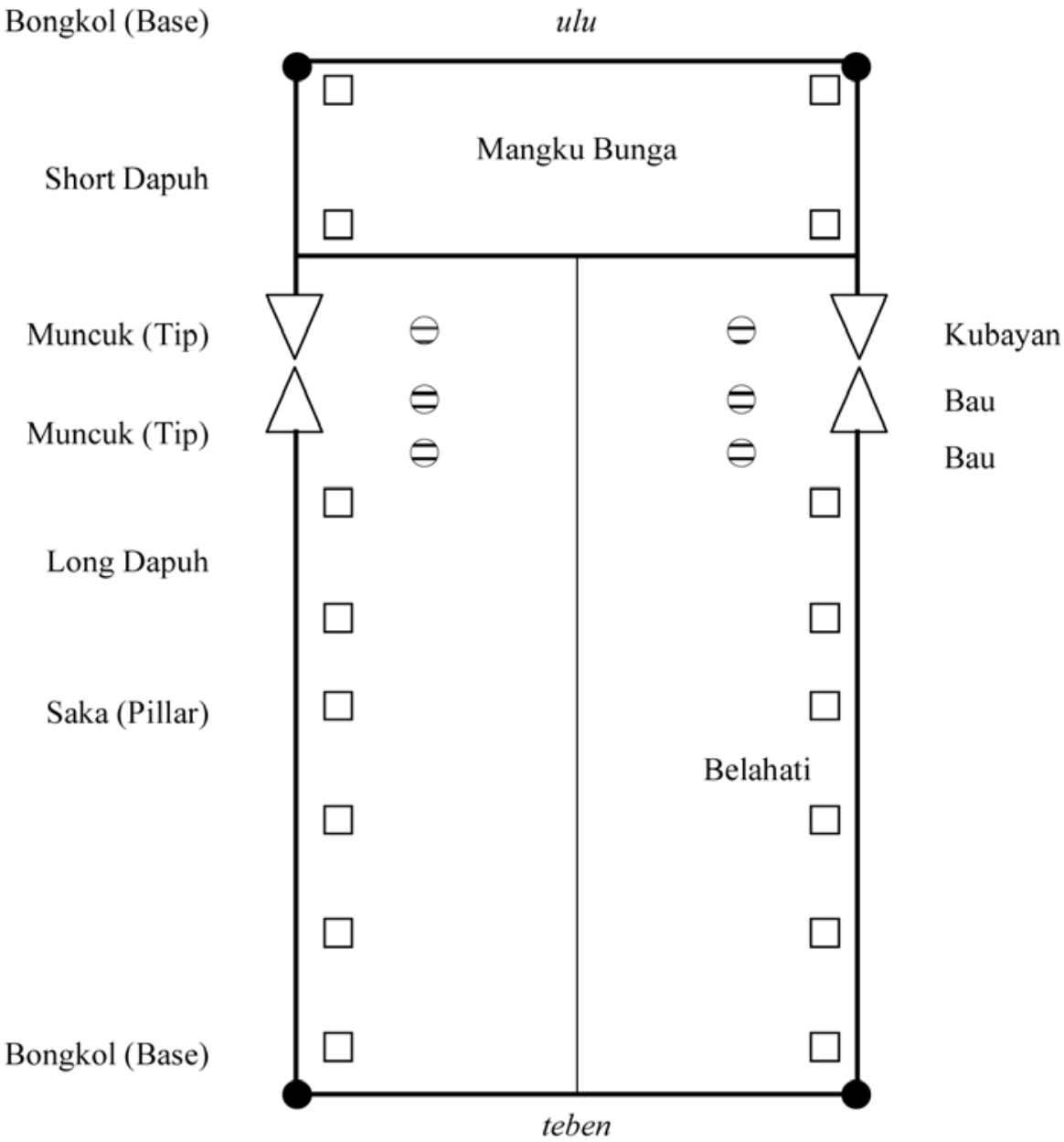

\section{Origin and precedence: the vertical axis of the ulu apad}

The case of Sukawana illustrates that access to status in the symbolic economies of Bali Aga villages is intimately connected with a person's relationship to the land, which is the primary resource of their material economies. Status may be distributed according to a rather equitable principle of precedence among those who are eligible to become full ulu apad members. However, a considerable proportion of the population is often excluded from the outset. A further tension arises because young men, though they may hope to rise to a position of authority in the future and are permitted to voice their opinion, must ultimately bow to the authority of older men. 
Bali Aga village councils are an attempt to emulate and control the temporal flux of social history. A person's social experience is regulated by his passage through a number of categorical life stages. Each stage signifies a specific relationship between the person and the community as a whole. The historicity of an agent is not denied, as it is in societies where status is determined by their birth into a specific status group and conceived of as an essential and permanent quality of their being. Rather, the individual's life journey is regulated by imposing upon it an itinerary which reflects and retraces the itinerary of his historical predecessors. Every society requires cultural reproduction, and all too often societies pursue this task by promoting the idea that society is part of an immutable order of things. What is exceptional about the ulu apad is that it explicitly depicts society as a historical process, as an evolving rather than static system.

A person's relative rank within an ulu apad is permanently set by an event, a conjuncture in time, which signals his or her entry into the adult community. This event is 'marriage', which is synonymous with 'forming a household' (makurenan) in the Balinese language. Marriage indicates a conjuncture of female (luh) and male (muani) and thus signals the end of a formal gender segregation during childhood and/or adolescence into sekaa daa and teruna. What transforms this into a social event is the formal recognition of the new household as a legitimate productive and reproductive unit. ${ }^{23}$

If marriage can be described as a foundation event, as the historical origin of a new house, then particular marriages bear a temporal relationship to one another in the course of social history in general. Each such event has precedents and successions, reproduces and is reproduced. It is exceptional that all events which are classified as a 'marriage' and lead to the formation of a 'household' within the village are regarded as part of a single, overarching sequence. In other parts of Indonesia, it is only marriages causally related to one another in a biological sense that are socially recognized as an order of precedence. In these societies, the historical movements of out-marrying sisters and their daughters is regarded as a 'flow of life' between patrifocal origin groups (for example, Fox 1980, 1990; Reuter 1993).

Marriage among Bali Aga is constructed as an event that concerns the village as much or more than it concerns the two sanggah (ancestor houses) from which the couple originate. How then is the symbolic potential of marriage claimed by the institution of the desa adat rather than remaining within the boundaries of an ideology of 'ancestry' or 'alliance'? It is in this context that the practice of paying bakatan (or tumbakan/kelaci) to the village reveals its full significance. These payments are required before a marriage is socially validated, not only in Sukawana, but in nearly all villages with an ulu apad. 
Once marriage has been constructed as a village affair, it can begin to serve as the basis of an index, the ulu apad, which relates each and every household in a specific way to the multitude of practices which make up the desa adat. The temporal sequence of marriages in a village establishes a rank order of precedence which is fixed in terms of the relative status of a member. The ancestors, as invisible members of the community, are the focus of a value orientation towards the past which renders the temporal ordering of households socially important. The value which permeates the organization of the ulu apad is that of 'origin'.

A second primary concern is to maintain an uninterrupted chain of links to the sacred 'source' which is represented by the elders and village ancestors. This desire to maintain a link with the original ancestors must be realized through the reproductive potential of their living successors. It is at this point where a status ambiguity arises between those whose seniority places them in the vicinity of the sacred origin of life, and those whose youthful potential of fertility places them in the vicinity of the sacred continuity of life. The constitutive events of this social order (marriages) are valued because they establish the conditions for the origin of new life in a procreational sense, a necessary material precondition for the perpetuation of the ulu apad. An unmarried man is unable to produce legitimate successors either for his kin group (sanggah) or for the village. The highly valued connection to ancestral origins is only 'alive' as long as it keeps on being reproduced from below, and hence each link in the sequence remains valid only so long as its representative remains productive (married and still nurturing dependents). ${ }^{24}$ In the day-to-day running of village affairs, this interdependence between 'trunk' and 'tip' or between old and young must be denied in practice so as to uphold the authority of the elders. For this tension there can only be symbolic compensation in strictly limited ritual contexts. In neighbouring Desa Bantang, for example, there is a temple festival involving the ritual theft of the elders' rank-specific food portions by village youths, after which the thieves must run the gauntlet between two rows of other youths who will pelt them with chillie-laced palm wine.

The ulu apad is mapped upon a process of biological and cultural reproduction. This 'mapping' departs from a simple recognition of the biological facts of life. Firstly, even though the value of biological reproduction (fertility) is frequently asserted, the practical importance of the young and reproductively active adult members of the ulu apad itself is concealed by projecting this value instead upon unmarried children with a mere fertility potential (daa teruna). The former are thus disassociated from the potential counter-value of fertility, while the daa and teruna - no matter how important their ritual function may be - have no chance of challenging the authority of the elders. Secondly, the idea of 'cultural reproduction' is firmly attributed to a process of initiation. Rather than emphasizing the socialization of children by their parents, cultural reproduction 
is represented in the desa adat as a process of transferring ritual knowledge from village elders to their successors.

\section{Complementarity and the lateral axis}

In the preceding discussion of the ulu apad the focus has been on how a sequence of marriages or household foundations is used to construct a social order of precedence. The lateral axis within the ulu apad itself has been all but ignored until now, namely, the fact that it consists not of a single file of predecessors and successors but of two parallel lines, or put another way, of a sequence of paired ranks and titles.

The constitutive pairs of the village assembly as such are not married couples but pairs of symbolically 'male' and 'female' men. The gender conjuncture sanctioned by marriage heralds a couple's entry into adulthood and the rank-order of the desa adat, an event marked by the culinary incorporation of their marriage prestations into the 'body' (or bodies) of the assembly. However, the final rite of entry into the assembly (menek makeraman) symbolically transforms opposite-gender pairs into pairs of men. The male members are divided into 'right' and 'left' or 'male' and 'female' ceremonial moieties. Among the more than 50 village assemblies examined in the course of this research, only a few were found to lack a moiety division. This moiety system is hedged in with sanctions, such as a prohibition to cross the belahati, the narrow central plank that divides the platform of a bale lantang into two sides.

Where left or right is located depends on whether one is facing kaja or kelod. Given that the Kubayan usually faces in the opposite direction to the other elders, it is a matter of choice whose orientation becomes determinative. Nevertheless, this and similar pairs of spatial categories that are used to distinguish between moieties (for example, 'east-west', 'inside-outside') are all concerned with a lateral axis of orientation. They distinguish between two locations which are at the same physical elevation, or two elders who hold the same rank or 'social elevation'.

In Sukawana the moieties are referred to by birth-order terms, as sibak tuaan and nyomanan ('older' and 'younger' sibling). During formal gatherings the Tuaan always sits on that side of the bale lantang which is facing the inner courtyard, while the Nyomanan sits on the side facing the outer temple wall. Given that bale lantang are almost always situated at the right hand side of the temple court (as seen from the main entrance at the kelod end of the temple) an inside/outside distinction would be redundant were it not for the fact that in the Pura Puseh of Sukawana, the bale lantang is deliberately placed at the left side. 
An explanation of this inversion and of how the two moieties are related in general is provided in one of Sukawana's origin narratives:

Once the king of Java sent five brothers to bring a gift to the king of Bali who resided at Balingkang (Dalem Balingkang). The gift was a small basket (sok) with the finest onion and garlic. However, the brothers became lost in the forest (wana) and failed to find the king's palace. Meanwhile the onion and garlic began to sprout and they had no choice but to plant them there and then, and to establish a camp. They named the location after this mishap (sok wana, hence Sukawana). When the new crop was harvested, a huge basket was filled and brought to the palace at Balingkang which they had finally managed to locate. The king complimented them on the fine flavour of the onion and garlic but noticed that it differed from the Javanese variety. So they narrated the events of their journey, and the king ordered three of the brothers to return to Sokwana and continue planting these crops. Wayan (the eldest brother) settled with his wife in Banjar Kelod and Made (the second born) in Banjar Kauh. Nyoman, the third and youngest brother, was still unmarried (teruna) and lived by himself in Banjar Jero. One morning he heard a cock crow and went to investigate. He discovered smoke coming from a house which belonged to a young girl (daa). They fell in love and were married. The land which had belonged to the girl was henceforth called Banjar Tanah Daa, and the residence of Nyoman was called Banjar Jero. The many houses in the three hamlets (banjar) of the three brothers still belong to a single origin temple (Pura Kawitan Pasek Bendesa). The descendants of the two elder brothers are called Tuaan, while those of the youngest brother and of the local bride's relatives are called Nyomanan.

The origin group 'Pasek Bendesa' are thus outsiders, but were the first to settle in what is now Sukawana. ${ }^{25}$ Like every mountain community, Sukawana's social order is modelled upon an underlying cosmic dualism, symbolically represented in the myth as bawang, red onion ('female') and kesuna, white garlic ('male'). These plants had to be put into the soil 'because they began to sprout', that is, the outsiders began to take roots in a new locality. The 'second crop', their offspring, 'took on a local flavour'. The newcomers, in this case, were installed on the inside. The youngest ('female') brother, Nyoman, facilitates this process by incorporating the indigenous population through marriage.

The Tuaan maintain a degree of dominance in several aspects of village life, as older brothers tend to have authority over their younger brothers. They provide the Kubayan Mucuk, the very highest authority in adat matters, and the Jejeneng Tengen, the worldly executive of the assembly. In most ritual matters (for example, buffalo sacrifices), however, the Kubayan Nyomanan will take the 
lead. One of the most pertinent expressions of this dual division is the association of the Tuaan with the Pura Bale Agung and the Nyomanan with the Pura Puseh. For example, during the great annual village festival (the usaba gede) each Tuaan household will offer one large rice cone (pendek) on the third day, in the Pura Bale Agung, while each nyomanan will offer a pendek on the fourth day, in the Pura Puseh. In general, the Nyomanan take precedence in organizing all rituals at the Pura Puseh, whereas the Tuaan have a greater part in the rituals of the Pura Bale Agung. ${ }^{26}$ The Pura Puseh (or 'navel temple') is associated with the ultimate origin of the village, with its land and with harvest rituals. ${ }^{27}$ The Pura Bale Agung is associated with government and official status; that is, with discussion and decision-making during the meetings of the council and with any ritual indicating a personal status change in relation to the ulu apad. In terms of ritual status, the Pura Puseh with its deities rank higher. For example, the offerings used on the fourth day of the usaba in the Pura Puseh will be re-used again on the fifth day in the Pura Bale Agung. This indicates that the deities of the latter can accept the left-overs (lungsuran) of the former while the reverse would be unthinkable.

In sum, the Nyomanan are associated with village origins and with the land while the Tuaan are outsiders from across the sea who established the order of the ulu apad and hold executive powers within it. Their seating position towards the temple court marks them as outsiders who have been installed on the inside. ${ }^{28}$ The Nyomanan are considered to form the 'left' part of the assembly which carries a 'female' connotation, as does their association with the 'younger sibling'. ${ }^{29}$ Likewise, the bale lantang in the Pura Puseh, associated with the Nyomanan, is on the left, which is the position of the women's longhouse (bale pelokayu) in the Pura Bale Agung.

Sukawana's origin narratives suggest that at some time in the past there was an influx of outsiders who were not only integrated into the local social organization but managed to gain political supremacy. ${ }^{30}$ In many other villages where sibak affiliation is hereditary, the 'right' side of the assembly is associated with an origin group who hold political privileges similar to those of Tuaan in Sukawana, privileges which are attributed to their status as local representatives of foreign kings. Such claims to an outside origin and an associated political authority may not always be based on historical fact, though it is likely that particular local factions gained control of the management of village relations through their association with external political authorities. 


\begin{tabular}{|l|l|}
\hline \multicolumn{2}{|c|}{ Paired Categories } \\
\hline Nyomanan & Tuaan \\
younger sibling & older sibling \\
left & right \\
'female' & 'male' \\
base (bongkol) & tip (mucuk) \\
insider (seated on the outside) & outsider (seated on the inside) \\
women's pavilion & men's pavilion \\
pavilion on the left (P. Puseh) & pavilion on the right (P.B. Agung) \\
\hline
\end{tabular}

This does not mean that the existence of ceremonial moieties can be explained entirely from an historical perspective of 'dual origins'. In this context it must be noted that in several other Bali Aga villages a man does not belong to his father's sibak because moiety affiliation is arbitrary and unrelated to ancestry (Figure 4). In the Sukawana type of village assembly, succession takes place in a bilinear fashion and there are separate rank lists for the two sibak (Type I). Each pair of elders is thus comprised of two men who have the same rank order number in their respective sibak. In a number of other villages (Kintamani, Pengejaran, Bayunggede, Bonyoh, Kayubihi, Batih, Lateng, Satra, Sanda, Cenigayan, Madenan and Sembiran) this is not the case. There, the division into sibak is purely symbolic, succession is unilinear, and only a single rank list is kept. As a man moves up through the ranks, he proceeds in a zig-zag pattern, alternating his symbolic sibak affiliation with every rise in rank (Type II). A man's entry into such an ulu apad always begins from the lowest position on the 'left'. The highest ranking keraman, the Kubayan Mucuk, always sits on the 'right' side.

Why is a lateral division into sibak considered so essential that it can be maintained independently of a notion of dual and separate ancestry? The insistence on paired elders or moieties in an ulu apad may derive from the Balinese cosmological principle of rua bineda; namely, that each living whole is necessarily composed of 'two [parts] which are different' and complementary in their function. The left-right division of village assemblies may be linked to observations of symmetry in nature, primarily in the human body, to which the structure of an ulu apad is said to correspond. This idiomatic focus on the lateral symmetry of the body does not take into account that 'bodies' can be male or female. The body symmetry of the ulu apad in effect substitutes body symmetry for gender bimorphism, thereby partially excluding women from what is meant to be a symbolic representation of the community as a whole. On a symbolic level, a 'male-female' couple is replaced with a pair of 'male' and 'female' men. Nevertheless, there is a residual awareness that such a pair, though it may suffice to form a symbolic whole, does not hold any potential for the biological 
reproduction of society. Marriage is thus the prerequisite for a man to become and remain a member of the assembly. ${ }^{32}$

Figure 4. Bilinear and unilinear succession in two types of ulu apad
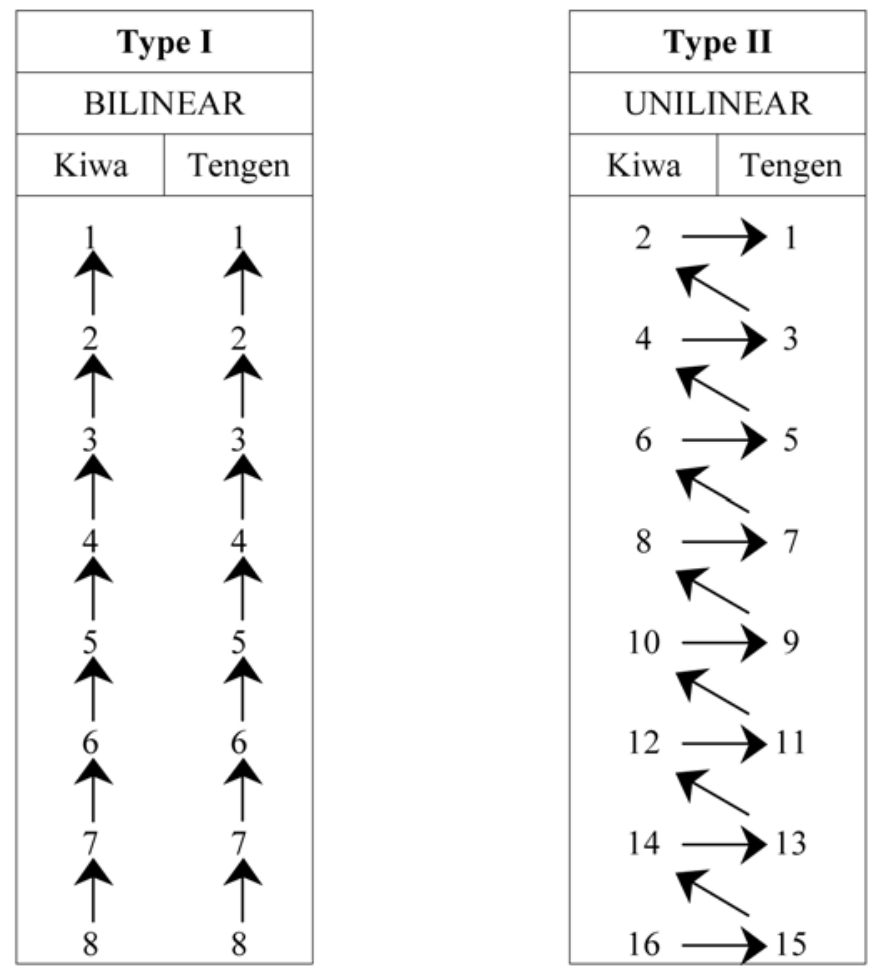

Perhaps the most fundamental difference between the two types of ulu apad is that in Type II, the vertical dyads of 'predecessors and successors' (in terms of rank level) are reproduced on the lateral axis of paired elders. In a unilinear (zig-zag) pattern of succession, one of the two elders in each pair (for example, 'Kubayan') is always the predecessor of the other since their rank order number differs (in this case \#1, \#2). Consequently, an asymmetric relationship between the two elders and the respective sibak is already anticipated within the pattern. In a Type I arrangement, this is not the case since both elders in a pair hold the same rank order number in relation to their respective sibak (for example, both 'Kubayan' are \#1). The notion of paired elders being 'equal in terms of precedence but different in kind' in Type I assemblies appears to be an innovation.

In sum, the ulu apad is characterized by a pairing of complementary categories on a lateral axis which intermeshes with a notion of temporal precedence in the vertical axis to produce a complex pattern of status distinctions. The logic of this pattern may be described as 'recursive dualism'. The pairing of male elders, as if they were couples, may in part be an ideological compensation for the 
virtual exclusion of women from positions of political and ritual leadership in Bali Aga society. But in many cases it is also a commentary on social and, most often, historical divisions between different origin groups within a village. As the example of Sukawana has illustrated, the relationship between powerful royal newcomers and ritually superior indigenous people in a village is like a miniature replica of the institutionalized relationship between Bali Aga and Bali Majapahit.

\section{Conclusion}

The preceding discussion of regional and local institutions has illustrated the paramount importance of 'origin' and 'precedence' as principles of vision and division within Bali Aga society. The value attached to these concepts is linked to an idea of the sacred as the domain of the deified ancestors and creator gods in whom human society has its ontological and historical origin. This orientation to a sacred origin is the basic criterion for ranking persons or person categories, distinguished as predecessors and successors within different social contexts and associated orders of precedence.

The value of origin is open to contestation both in its contextual definition and in its historical interpretation. Evidence of conflicting views and of associated status struggles are more clearly visible in regional and loosely structured domains than they are in the tightly organized villages of highland Bali. The membership and status of a village within a domain is ultimately voluntary and negotiable, but the negotiation takes place in an idiom of precedence. Even at the village level, there is at least some scope for contesting the rules of eligibility for joining a village council or for questioning the distribution of authority among its moieties by proposing different definitions or interpretations of origins.

These observations have important implications for deciding on the prospects of a cross-cultural or universal theory of status.

1) In view of the findings presented by other contributors to this volume it has become evident that the same logic of origin and precedence that informs the symbolic economy of Bali Aga society is also a fundamental principle of vision and division in other Austronesian societies. This confirms that a general theory of precedence can offer a high degree of cross-cultural validity as an analytical tool for the social analysis of many societies within this larger region. It was also noted that the time-based principle of precedence is very dissimilar to the substance-based principle of purity and pollution that informs the symbolic economy of the Indian caste system. In short, the predictive power of a cross-cultural theory of status tends to be directly proportional to the degree of cultural similarity among the symbolic economies it seeks to explain.

2) Origin is an 'absolute' value in its spiritual aspect (as a concept of the sacred), but it also encourages an interpretation and construction of 'the sacred' 
(society) in terms of a relativistic temporal logic of status distribution. The social outcome are rank orders of precedence with a shifting but nonetheless unequal distribution of symbolic capital. This suggests that a universal theory of status may still be possible, though only insofar as we may assume that the core values of all societies reflect the same human desire for a vision of unity or wholeness as well as a proclivity for dividing the whole, and that every society is therefore to some degree a hierarkhia. Indeed, in one sense every society (or its privileged members) must evoke its own sacredness as a society (on the grounds of the self-transcending social experiences of individual agents) in order to legitimize and reproduce its particular pattern of symbolic capital distribution. An absolutely 'egalitarian' society would lack a symbolic economy, and such societies do not exist. ${ }^{33}$

3) The notion of origin in itself does not normally specify precisely who will precede whom in different contexts. Between the positing of the sacred or 'universal' and the creation of a specific status system lies an important step of interpretation. Interpreting agents have two stakes, one in their own particular symbolic interests and another in maintaining their social co-operation with others (to satisfy collective interests and to define the rules of the game that makes status competition possible in the first place). It may thus be argued that any symbolic economy exists in a state of tension; between stability and change, consensus and contestation, totalizing values and value fragmentation. For example, in order to retain a continuous chain of links to its sacred origins in the past, the social order must reproduce itself in the here and now. This evokes a residual counter value of human sexuality and worldly immanence as opposed to the disembodied transcendence of the deified ancestors. In short, there are no utterly non-egalitarian societies either. Labelling other societies as essentially 'hierarchical' comes at the risk of endorsing their local totalizing discourses (which may proclaim the dominance of one value or value sphere over all others), and of ignoring the presence of counter discourses and other forms of resistance.

4) In any symbolic economy some participants are disadvantaged. It is difficult but possible to ensure that they tolerate this fact or that it escapes their full recognition. Status differences in an order of precedence, for example, are relatively small, transient and easily tolerated. Nevertheless, it seems that the disadvantages that do exist are significant enough to create a need for a social technology of hierarchization, a technology for preventing the rise of widespread social discontent. A recognition of disadvantage may be prevented by the natural enchanting power of the sacred, the lived experience of partaking in a group or society. However, that this enchantment should permanently outweigh experiences of disenchantment and symbolic violence cannot be assumed to be a natural state of affairs. The form of hierarkhia that is characteristic of Bali Aga society evidently requires for its maintenance a tremendous investment of time, effort and material resources into producing heightened experiences of sociality 
- in the context of joint ritual. These experiences of sacred socialityare apparently intense and formative enough to ameliorate people's lived experiences of a lack of social unity in every-day life, though they are insufficient to prevent conflict altogether.

\section{References}

Bellwood Peter, James J. Fox and Darrell Tryon (eds)

1995 The Austronesians: historical \& comparative perspectives. Canberra: Department of Anthropology, Research School of Pacific and Asian Studies, The Australian National University. Comparative Austronesian Series, ANU E Press: http://epress.anu.edu.au/.

Dumont, L.

1980 Homo hierarchicus: the caste system and its implications. Revised English edition. Chicago: The University of Chicago Press.

1986 Essays on individualism: modern ideology in anthropological perspective. Chicago: The University of Chicago Press.

Fox, James J.

1980 Introduction. In James J. Fox (ed.), The flow of life: essays on eastern Indonesia, pp.1-18. Cambridge, MA: Harvard University Press.

1988 Origin, descent and precedence in the study of Austronesian societies. Public lecture in connection with De Wisselleerstoel Indonesische Studiën, 17 March 1988, Leiden.

1989 Category and complement: binary ideologies and the organization of dualism in eastern Indonesia. In David Maybury-Lewis and Uri Almagor (eds), The attraction of opposites: thought and society in the dualistic mode, pp.33-56. Ann Arbor: University of Michigan Press.

1990 Hierarchy and precedence. Working Paper No. 3, Comparative Austronesian Project. Canberra: The Australian National University.

1993 Comparative perspectives on Austronesian houses: an introductory essay. In James J. Fox (ed.), Inside Austronesian houses: perspectives on domestic designs for living, pp.1-29. Canberra: Department of Anthropology, Research School of Pacific and Asian Studies, The Australian National University. Comparative Austronesian Series, ANU E Press: http://epress.anu.edu.au/.

1994a Reflections on hierarchy and precedence. History and Anthropology 7(1-4):87-108. 
1994b Installing the 'outsider' inside: an exploration of an Austronesian cultural theme and its social significance. First International Symposium on Austronesian Cultural Studies. Universitas Udayana, Bali: 14-16 August 1994.

Fox, James J. and Clifford Sather (eds)

1996 Origins, ancestry and alliance: explorations in Austronesian ethnography. Canberra: Department of Anthropology, Research School of Pacific and Asian Studies, The Australian National University. Comparative Austronesian Series, ANU E Press: http://epress.anu.edu.au/.

Graham, P.

1991 To follow the blood: the path of life in a domain of Eastern Flores. Unpublished PhD thesis. Canberra: Department of Anthropology, The Australian National University.

Guermonprez, J.-F.

1990 On the elusive Balinese village: hierarchy and values versus political models. Review of Indonesian and Malaysian Affairs 24:55-89.

Lansing, J.S.

1987 Balinese water temples and the management of irrigation. American Anthropologist 89(1):326-341.

1991 Priests and programmers: technologies of power in the engineered landscape of Bali. Princeton (NJ): Princeton University Press.

Lewis, E.D.

1988 People of the source: the social and ceremonial order of Tana Wai Brama on Flores. Verhandelingen van het Koninklijk Instituut voor Taal-, Landen Volkenkunde 135. Dordrecht, Holland/Providence, USA: Foris Publications.

MacRae, G.

1995 Ubud: cultural networks and history. Paper presented at the Third International Bali Studies Conference at the University of Sydney, 3-7 July 1995.

Marriott, McKim

1976 Hindu transactions: diversity without dualism. In Bruce Kapferer (ed.), Transaction and meaning: directions in the anthropology of exchange and symbolic behavior, pp.109-142. Philadelphia: Institute for the Study of Human Issues. 
McWilliam, A.R.

1989 Narrating the gate and the path: place and precedence in South West Timor. Unpublished PhD thesis. Canberra: Department of Anthropology, The Australian National University.

Platenkamp, J.D.M.

1990 Some notes on hierarchy in Eastern Indonesia: a comment on J.J. Fox's 'Hierarchy and precedence'. Paper presented at the Conference on Hierarchy, Ancestry and Alliance, The Research School of Asian and Pacific Studies, The Australian National University. Canberra: 25-30 January 1990.

Reuter, T.A.

1993 Precedence in Sumatra: an analysis of the construction of status in affinal relations and origin groups. Bijdragen tot de Taal-, Land-en Volkenkunde $148(3,4): 489-520$

1996 Custodians of the sacred mountains: the ritual domains of highland Bali. Unpublished PhD thesis. Canberra: Department of Anthropology, The Australian National University.

1998 The Banua of Pura Pucak Penulisan: a ritual domain in the highlands of Bali. Review of Indonesian and Malaysian Affairs 32 (1):55-109.

1999 People of the mountains - people of the sea: an Indonesian cultural theme and the negotiation of marginality in modern Bali. In L. Connor and R. Rubinstein (eds), Staying local in the global village: Bali in the twentieth century, pp.189-216. Honolulu: University of Hawaii Press.

2002a Custodians of the Sacred Mountains: culture and society in the highlands of Bali. Honolulu: Hawaii University Press.

2002b The house of our ancestors: precedence and dualism in highland Balinese Society. Koninklijk Instituut voor Taal-, Land- en Volkenkunde, Verhandelingen 198. Leiden: KITLV Press.

Supomo, S.

1995 Indic transformation: the Sanskritization of Jawa and the Javanization of the Bharata. In Peter Bellwood, James J. Fox and Darrell Tryon (eds), The Austronesians: historical \& comparative perspectives, pp.291-313. Canberra: Department of Anthropology, Research School of Pacific and Asian Studies, The Australian National University. Comparative Austronesian Series, ANU E Press: http://epress.anu.edu.au/. 
Vischer, M.P.

1992 Children of the black patola stone: origin structures in a domain on Palu'é Island, eastern Indonesia. Unpublished PhD thesis. Canberra: Department of Anthropology, The Australian National University.

\author{
Wurm, S.A. and B. Wilson
}

\title{
1975 English finderlist of reconstructions in Austronesian languages (post Brandstetter). Pacific Linguistics, Series C, No. 33. Canberra: Department of Linguistics, Research School of Pacific Studies, The Australian National University.
}

\section{ENDNOTES}

${ }^{1}$ This paper is based on ethnographic field research carried out in 1993-94 (see Reuter 1996) and during several shorter visits until the present, funded predominantly by the Australian Research Council. Dr Reuter is currently a Senior Research Fellow in Anthropology within the School of Political and Social Inquiry at Monash University.

2 The valency of the relationship may at times appear to suffer an inversion in the course of specific changes in the political history of a polity. In Bali, for example, the descendants of Majapahit immigrants enjoy a higher status than the Bali Aga in most social contexts, even though the latter are presumed to be a remnant of Bali's original settlers. The newcomers successfully proposed a 'new' and external origin for Bali, on the assumption that its civilization was not merely added to but created by Majapahit. The Bali Aga, of course, hold different views on the matter.

3 Purity, according to Dumont the singular and all-encompassing value of Indian social hierarchy, is a pertinent example, for does it not conjure up an entity or state without attribute, colour, taste or otherwise differentiated substance? Purity is a vacuum, a silent emptiness at the eye of a storm of social ambitions. It is for Indian society almost what the Indian concept of zero is for mathematics. In this sense Dumont's claim that the value of purity is all-encompassing cannot be debated. However, this does not rule out the existence of alternative Indian values, or of rival interpretations of what purity means in relation to the status of particular human beings.

4 Durkheim's own theory of modernity also tends to discount the importance of 'the sacred' (the experience of the social) in modern societies. He suggests that the individual subject's capacity for introspective moral judgement has eclipsed society as the fountain of sacred or universal normative standards. For Durkheim, this normative weakness of modern society was merely the symptom of a transition state from mechanical to organic solidarity, but until now history has led to such a transition. 5 Further regional similarities were observed at the level of kinship and affinal relations.

6 A clear distinction between the religious and political domains of life is not easily drawn in relation to Bali Aga society. In Bali generally, political protests are frequently phrased in a religious idiom. Open opposition to the national government was not tolerated until after the fall of the Suharto regime in 1998.

7 The complex process of dissecting and reconstructing a sacrificial body in Bali Aga ritual, which is the main focus of ritual labour, presents an image of society as a 'body' that is not just received as a given and 'natural' order but created and constantly re-created. The wholeness of the sacrificial body may be a sacred given, but what counts is how it is carved up, and in the end, who receives which part of (and status within) this body during a subsequent communal ritual meal.

8 Pangamong is derived from among, 'to take care of/stand guard' or ameng, 'to hold or wield a weapon'. Pangempon is derived from empon, 'to take care of a task'/'to organize an event' or empu, 'to nurse or look after [a child]'.

9 Some exceptional cases were observed where only one faction within a village joined a banua temple in another village. In all of these cases, this was indicative of an acute power struggle in the branch village.

10 Several subcategories of reconstructions of the Proto-Austronesian word for 'leaf' ( ${ }^{*} d a^{\prime} u n$, whereby

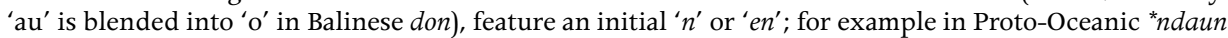


(Wurm and Wilson 1975:118). This may explain the derivation of the Balinese verb endon ('to come, arrive'), which is commonly regarded as the free morpheme in pendonan.

11 For example, if the core group of 'founders' within a client village loses political and ritual control to their own immigrant clients, the latter may decide to detach the entire village from the cult of the banua temple in the origin village. In general, such a separation is implemented by conveniently 'forgetting' an earlier obligation. Open confrontation would only reduce the status of both parties.

12 For comparison I refer to the research of Graeme MacRae (1995) concerning ritual connections between the temples in Wos valley communities and Pura Gunung Lebah in Ubud, and to Lansing's (1987) work on ritual networks relating to irrigation in Bali.

13 Crops are normally divided equally between land-owner and share-cropper.

14 Sukawana does not have land classified as AYDS, but in other Bali Aga communities it can amount to more than two thirds of all arable land. The desa is thus not merely a site for negotiating a local status distribution. It is often just as relevant to the control of material resources.

15 This device is called pangeling-ngeling desa (lit. 'circling or rotating of the village'), and I thank the Kepala Desa of Dausa for allowing me to study one of the few remaining specimens.

${ }^{16}$ The term 'Pura Bale Agung' ('temple of the great pavilion') is a common designation of a type of temple which is found in nearly all Balinese villages. In the highlands the temple is popularly known as Pura Desa. 'Pura Bale Agung' is somewhat of a misnomer in that there are also ceremonial longhouses (bale agung or bale lantang) in the Pura Puseh and Pura Dalem of many mountain villages.

17 Note that both in ritual and every-day speech contexts, it is always 'left and right' rather than 'right and left'. Likewise, people always say luh-muani (female and male) and daa-teruna (girls and boys).

18 A male-female sibling pair in mythology usually incorporates an older brother and younger sister, thus equating 'younger sibling' with 'female'. A couple before they are married will address one another as kaka (older sibling, female addressing male) and adi (younger sibling, male addressing female). Also, young men are often accused of going to the temple only 'to worship Dewa Nyoman and Dewa Ketut (third and fourth born)', which means that they only attend to perve at the young girls in their tight sarongs. Younger brothers are symbolically equated with females in that they — like the sisters - tend to receive less of the paternal inheritance than their older brothers and are somewhat subservient to them until they are married.

19 Only a detailed discussion of ritual processes would suffice to provide the contextual information necessary in order properly to appreciate the ritual and social responsibilities of elders in accordance with their rank. However, it is worth pointing out that one context from which the titles of Sukawana elders are symbolically derived is the division of sacrificial animals; namely, the victim's forelegs. Specific parts of the forelegs at first become part of the wangun urip, an offering consisting of selected bones which are rearranged as if the animal were 'brought to life again'. After the urip has been offered to the gods these bones are divided among elders according to rank. The term Bayan refers to the centre of the body (bayan 'heart') and the Jero Kubayan's portion is the tip of the shoulder blade, closest to the heart or spine. The Jero Bau (bau 'shoulder') receives the remainder of the shoulder blade along with the shoulder joint (tulang tambah). The Jero Singgukan (singguk '[to nudge with] the elbow'), in turn, receives the elbow joint ( $s i k u)$. The tip of the foreleg, including the hoof $(k u k u)$ is shared equally among the top thirteen elders. The right and left forelegs belong to the elders of the Tuaan (right) and Nyomanan (left) respectively. Possibly, the title Pengelanan is derived from this schema as well (pagelangan 'wrist').

20 Such service was expected of unmarried men (teruna). Until today their ritual duties include the performance of a spear dance (baris tumbak teruna).

21 It is also possible that the word bakatan derives from bokat, 'a short spear'.

22 These paired terms, muncuk and bongkol, also imply a distinction of male and female in that they also carry the meaning of 'penis' and 'vagina' respectively. Since the sibak tuaan is symbolically 'male', the Kubayan Tuaan is also referred to as 'Kubayan Mucuk'. The title mucuk is a contraction of the word muncuk ('tip [of a plant]' or 'penis'), or may be the transitive form of pucuk or pucak, both of which indicate a 'tip, pinnacle, or peak [of a mountain]'.

23 This interpretation can be supported by reference to situations which depart from the ideal script. Sexual liaisons before marriage are generally discouraged, but are by no means uncommon. If such liaisons become continuous and public knowledge, parents or village leaders will strongly urge or even force the couple to marry.

24 Just as the upward end of an ulu apad points beyond, towards disembodied and deified predecessors, so is its lower end directed at unborn future successors with similar qualities. In some villages the daa and teruna (one sibling pair from each household) are ranked by seniority and led by a Kubayan Teruna 
(for example, Kintamani), which suggests that brother-sister pairs form a symbolic extension of the $u l u$ apad at its lower end. In Bali Aga mythology, such brother-sister pairs are of great importance, for example, in the tale 'I Barak-Ni Petak' ('red [brother] and white [sister]') from the Lake Batur area. Generally, red represents 'female' (blood) and white represents 'male' (semen). In this myth, however, the B-Z pair of twins eventually become a H-W pair. After their marriage they are called Ni Barak and I Petak (red female-white male).

25 Sukawana is first mentioned in prasasti Kintamani C (ca. AD 970) as Kintamani's northern boundary. According to one legend, old Sukawana (Kuta Dalem) was one desa adat with Kintamani until newcomers established the main settlement on the northern slope (contemporary 'Sukawana') and shifted the Pura Bale Agung and Pura Puseh.

${ }^{26}$ For example, the Kubayan Kiwa dedicates the offerings and only the Mangku Bunga Kiwa may carry the sacred objects during the festival of the Pura Puseh. All offerings are prepared by the women of the Nyomanan (kiwa). By contrast, the festival of the Pura Bale Agung coincides with that of the Bendesa clan temple controlled by the Tuaan.

27 In Desa Julah, for example, the deity of the Pura Puseh is called Ratu Maduwe Karang, 'the deity who owns the land'.

${ }^{28}$ Placing the 'outside' at the 'tip', and the 'inside' at the base, is a variant of this arrangement transposed to a vertical axis of orientation. During post-mortuary ritual, a temporary pavilion in the house yard is decorated with two specific cloths. At the upper end or 'tip' a Chinese gold-embroidered cloth (kain lelintangan, 'cloth brought from far away') is placed, symbolizing the newly imported from the outside world. At the lower end or 'base' a Balinese double-ikat cloth from Tenganan (kain geringsing, 'cloth of no illness') is placed, symbolizing the ancient and indigenous.

29 The sister in Bali Aga mythology is almost always a younger sibling (adi), and men often address their lovers or wives as 'younger sibling'.

30 A conceptual distinction between 'locals' and 'newcomers' need not be based on an actual historical migration, although in this case it probably did occur.

31 The head elder of the right is always called Mucuk ('tip', also 'penis'), and thus corresponds to the upper end of the vertical axis. The symbolic correspondence between the left side of the lateral axis and the lower end of the vertical axis (both 'female') is expressed very openly in Desa Les, where the sibak tengen all face ulu, whereas the sibak kiwa face teben during formal meetings.

32 he importance of women is also acknowledged in temple design. Many Bali Aga villages have a women's as well as a men's pavilion. While men and women may both gather in their respective 'longhouses' on a full moon (in some villages), only men are allowed to attend the new moon meetings in which all important community matters are decided.

33 In modern consumer societies the importance of the symbolic economy may have been eclipsed with an increasing public focus on the material economy, whereby wealth acquires ascendency even as a status indicator. Such restricted symbolic economies are not necessarily more egalitarian, even though the stakes of the game of status competition may be reduced because status becomes an adjunct to wealth. Status also endures as an end in itself in many sectors of modern society, not the least in the academic world. In some post-modern religious systems we can observe that status and sacredness are becoming divorced from the numinous experience of the social (which many people now lack) and are referenced more directly to people's numinous experience of objective reality. Balinese too recognise this possibility within their esoteric religious systems, wherein the 'status' of a person is defined by their capacity to enter into personal communion with sacred as an objective reality (the spirit world or niskala) rather than by their formal position within society or their role in relation to public ritual. 